УДК 338.242

Вороніна В.Л., к.е.н., доцент

Спінжар Р.В., магістрант

Полтавська державна аграрна академія

\title{
АНАЛІЗ ПІДХОДІВ ДО ВИЗНАЧЕННЯ ПОНЯТТЯ ЕКОНОМІЧНОЇ БЕЗПЕКИ ПІДПРИЕМСТВА
}

\begin{abstract}
У статті проведено семантичний аналіз сутності поняття «економічна безпека», що дозволило поєднати два поняття: «економічний» та «безпека». Сформовано перелік характеристик, які використовуються вченими в ході визначення поняття «економічна безпека». Встановлено, що такими характеристиками є: забезпечення стійкого зростання; виживання системи; задоволення потреб; захист інтересів; ефективне управління; зміцнення потенціалу; подолання загроз і забезпечення стійкості до них; стабільне функціонування; збереження існуючого статусу; максимізація віддачі; спроможність до самовідтворення; протистояння впливу чинників; забезпечення конкурентоспроможності. Отримані результати дають змогу поглибити та розширити теоретико-методичні основи оцінки рівня економічної безпеки підприємств.
\end{abstract}

Ключові слова: аналіз, безпека, економічна безпека, ефективність, підприємства.

Voronina V., Spingar R.

\section{ANALYSIS OF APPROACHES TO DEFINING THE CONCEPT OF ECONOMIC SECURITY OF THE ENTERPRISE}

Much research has been done on economic security in Ukraine and in the world. This is due to the deterioration of the sustainable and stable development and functioning of the business. Today the characteristics of economic security of enterprises have not been investigated. The views of scientists are different. The purpose of the study is to identify theoretical and methodological approaches to the concept of "economic security". Business security is the basis for maintaining a stable competitive position. This is the basis for effective enterprise development. There is no single definition of security among scientists. The author considered different security concepts. The most common is the definition of enterprise security as a state of efficient use of its resources (capital resources, personnel, information and technology, machinery and equipment, rights) and market opportunities. Allows you to counteract internal and external negative threats. And ensure the survival and development of the market. The central security of the enterprise is economic security. Economic security of the enterprise is the mode of the best economic effect from the activity of the enterprise.

Keywords: analysis, security, economic security, efficiency, enterprises.

Воронина В.Л., Спинжар Р.В.

\section{АНАЛИЗ ПОДХОДОВ К ОПРЕДЕЛЕНИЮ ПОНЯТИЯ ЭКОНОМИЧЕСКОЙ БЕЗОПАСНОСТИ ПРЕДПРИЯТИЯ}

В статье проведен семантический анализ сущности понятия «экономическая безопасность». Сформировано перечень характеристик, которые используются учеными в ходе определения понятия «экономическая безопасность». Установлено, что такими характеристиками является обеспечение устойчивого роста; выживание системы; удовлетворение потребностей; защита интересов; эффективное управление; укрепление потенциала; преодоления угроз и обеспечения устойчивости к ним; стабильное функционирование; сохранение существующего статуса; максимизация отдачи; способность к самовоспроизведению; противостояния влиянию факторов; обеспечение конкурентоспособности. Полученные результаты позволяют углубить и расширить теоретико-методические основы оценки уровня экономической безопасности предприятий.

Ключевые слова: анализ, безопасность, экономическая безопасность, эффективность, предприятия.

Постановка проблеми у загальному вигляді i iї зв'язок 3 важливими науковими та практичними завданнями В умовах динамічного зовнішнього середовища та нестійкого розвитку національної економіки вітчизняні підприємства стикаються з безліччю загроз для свого функціонування. Насамперед, це пов'язано 3 
погіршенням сталого та стабільного розвитку і функціонування підприємств, відсутності сприятливих умов для ведення та підтримання ефективної підприємницької діяльності, що викликано економічною нестабільністю, наявності протиріч у законодавчій базі та кризовими явищами грошово-кредитної системи та валютного ринку країни. Відповідно виникає необхідність побудови організаційно-економічного механізму підприємства, що здатен ефективно протидіяти загрозам та викликам безпеці підприємств. Набувають актуальності питання уточнення сутності поняття економічної безпеки, що є запорукою створення відповідних систем управління економічною безпекою на підприємствах.

Востаннє все більше досліджень в Україні та світі присвячується питанням визначення та особливостей економічної безпеки. Але, на сьогоднішній день, практично не дослідженими $€$ сутнісні та змістовні характеристики економічної безпеки підприємств; не визначені підходи до оцінки рівня економічної безпеки; не достатньо висвітлені питання можливості підвищення рівня економічної безпеки в процесі фінансово-господарської діяльності; не розроблені наукові положення щодо системи фінансової безпеки підприємств в сучасних умовах господарювання. Все це обумовлює необхідність дослідження, а недостатня розробка теоретичних положень визначає доцільність його проведення.

Аналіз останніх досліджень, у яких започатковано вирішення проблеми. Питання, пов'язані з методологічними підходами щодо формулювання сутності економічної безпеки підприємства широко розглядаються в багатьох наукових роботах. Дослідженням поняття саме економічної безпеки займались такі науковці, як А. Архипов, О. Бєлов, І. Богданов, А. Большаков, Д. Буркальцева, 3. Варналій, О. Гальцова, В. Гончарова, В. Духов, А. Іларіонов, Я. Жаліло, В. Коваль, А. Лазарева, Т. Логутова, Е. Микульчинова, А. Нестеренко, О. Прокопішина, В. Тарасевич, І. Черняков та ін.

Цілі статті. У результаті дослідження генезису теорії безпеки підприємств, на основі критичного аналізу фундаментальних праць вітчизняних та зарубіжних науковців, виявлено існування різноманітних підходів до тлумачення змісту даного поняття. Також, тривають дискусії відносно концептуальних підходів до визначення сутності поняття «економічна безпека»; щодо спектру функціональних складових цієї категорії, складу оціночних критеріїв тощо. Метою дослідження $\epsilon$ визначення теоретикометодичних підходів щодо сутності поняття «економічна безпека».

Виклад основного матеріалу дослідження 3 повним обгрунтуванням отриманих наукових результатів. Забезпечення належного рівня безпеки бізнесу $\epsilon$ однією із фундаментальних засад підтримання його життєздатності в умовах динамічного економічного середовища.

Управління безпекою є вагомим, невід'ємним елементом культури ведення бізнесу, а згідно з сучасним поглядам - якості бізнесу в цілому. Безпека бізнесу є основою збереження стійких конкурентних позицій, передумова ефективного функціонування та стабільного розвитку суб'єкта господарювання.

Вівчар O. I. зазначає, що якість бізнесу визначається такими основними елементами: економічна ефективність; соціальне спрямування; безпека [1, с. 194].

Серед учених немає єдиного визначення терміну «безпека». Розглянемо уточнення дефініції безпеки підприємства в табл. 1.

Отже, наукова категорія «безпека» визначається 3 різних позицій. Зокрема, Платонов А. М. зазначає, що безпека - це стан захищеності життєво важливих інтересів особистості, суспільства й держави від внутрішніх і зовнішніх загроз [7].

На думку автора, найбільш поширеним є визначення безпеки підприємства як стану ефективного використання його ресурсів (ресурсів капіталу, персоналу, інформації і технології, техніки та устаткування, прав) і існуючих ринкових можливостей, що дозволяє запобігати внутрішнім i зовнішнім негативним впливам (загрозам) i забезпечити його тривале виживання і стійкий розвиток на ринку відповідно до обраної мiciï. 
Таблиця 1.

Визначення поняття «безпека підприємства» у науковій літературі

\begin{tabular}{|l|l|}
\hline \multicolumn{1}{|c|}{ Автор, джерело } & \multicolumn{1}{c|}{ Визначення } \\
\hline $\begin{array}{l}\text { Евдокимов Ф. I. } \\
\text { [2] }\end{array}$ & $\begin{array}{l}\text { становище найбільш ефективного використання ресурсів для запобігання загроз } \\
\text { i забезпечення стабільного функціонування підприємства на теперішній час і в } \\
\text { майбутньому }\end{array}$ \\
\hline Кавун С. В. [3] & $\begin{array}{l}\text { захищеність його діяльності від негативного впливу зовнішнього оточення, а } \\
\text { також здатність своєчасно усунути різноманітні загрози або пристосуватися до } \\
\text { iснуючих умов, які не відбиваються негативно на його діяльності }\end{array}$ \\
\hline Довбня С. Б. [4] & $\begin{array}{l}\text { комплекс заходів, які сприяють підвищенню фінансової стійкості господарчих } \\
\text { суб'єктів за умов ринкової економіки, які захищають їх комерційні інтереси від } \\
\text { впливу негативних ринкових процесів }\end{array}$ \\
\hline Геєць В. М. [5] & $\begin{array}{l}\text { сукупність чинників, які забезпечують незалежність, стійкість, здатність до } \\
\text { прогресу в умовах дестабілізуючих факторів }\end{array}$ \\
\hline Дацків Р. М. [6] & $\begin{array}{l}\text { захищеність його науково-технічного, технологічного, виробничого та } \\
\text { кадрового потенціалу від прямих (активних) або непрямих (пасивних) загроз }\end{array}$ \\
\hline \multicolumn{2}{c}{ систематизовано автором }
\end{tabular}

3 точки зору самостійності, безпека визначається як стан суспільних відносин. При цьому стані особистість, соціальна група, народ, країна (держава) може самостійно, суверенно, без втручання й тиску ззовні вільно обирати й здійснювати свою стратегію міжнародної поведінки, духовного, соціально-економічного й політичного розвитку [2, c. 202].

Большаков А. К та ін. розглядають безпеку з позицій ризикованості. «Безпека - це відсутність неприпустимого ризику, пов'язаного 3 можливістю завдання збитків» [8, c. 156].

Центральною ланкою забезпечення безпеки підприємства взагалі є економічна безпека суб'єкта господарювання. Економічна безпека підприємства - це режим забезпечення отримання найкращого економічного ефекту від функціонування суб'єкта господарювання у вигляді прибутку чи досягнення соціальної мети.

3 метою дослідження сутності поняття «економічна безпека» нами було проведено його семантичний аналіз, що дозволило поєднати два поняття: «економічний» та «безпека».

Логутова Т. Г. та Нагаєвський Д. І. розглядають прикметник «економічний» на державному рівні: «...пов'язаний із суспільно-виробничими відносинами або ж зі станом господарства певної країни (станом національної економіки)» [9, с. 204].

Якщо говорити про поняття «безпеки», то в тлумачному словнику з української мови наводиться досить однозначне його трактування - як стан, коли кому-небудь або чому-небудь ніщо не загрожує [10].

Поєднання семантичних смислів двох понять «економіки» та «безпеки» здійснювали багато науковців. Але, не дивлячись на пильну увагу до вивчення сутності поняття «економічної безпеки», підходи до її визначення, далеко не завжди охоплюють всю його багатогранність.

Вважаємо, що економічну безпеку підприємства можна розглядати як одну 3 складових загального поняття «безпека». Поглиблений теоретичний аналіз поняття «економічна безпека підприємства» 3 боку систематизації та структурування приведено в табл. 2.

Погоджуємося, економічна безпека підприємства - поняття комплексне. Воно включає в себе сукупність факторів, пов'язаних не стільки з внутрішнім станом самого підприємства, скільки з впливом зовнішнього середовища, з якими підприємство вступає у взаємозв'язок. 
Таблиця 2.

Аналіз визначень наукового поняття «економічна безпека підприємства» *

\begin{tabular}{|c|c|}
\hline Автор, джерело & Визначення \\
\hline Дацків Р. М. [6] & $\begin{array}{l}\text { такий стан економічного розвитку суб’єктів господарювання (особи, } \\
\text { держави, організації), який забезпечує йому гармонійний розвиток і } \\
\text { ефективне використання шансів і усунення загроз оточуючого } \\
\text { середовища }\end{array}$ \\
\hline Платонов А. М. [7] & $\begin{array}{l}\text { стан захищеності його діяльності від зовнішніх і внутрішніх загроз, а } \\
\text { також здатність адаптуватися до існуючих умов, які не впливають } \\
\text { негативно на його діяльність }\end{array}$ \\
\hline Логутова Т. Г. [9] & $\begin{array}{l}\text { стан виробничо-економічної системи, при якому функціонують механізми } \\
\text { запобігання чи зменшення ступеня впливу погроз стабільності } \\
\text { функціонування і розвитку підприємства }\end{array}$ \\
\hline Олейников С. А. [11] & $\begin{array}{l}\text { стан найбільш ефективного використання корпоративних ресурсів для } \\
\text { подолання загроз і забезпечення стабільного функціонування } \\
\text { підприємства тепер і в майбутньому }\end{array}$ \\
\hline $\begin{array}{l}\text { Ілляшенко С. І. [12] } \\
\text { Кузенко Т. Б. [13] }\end{array}$ & $\begin{array}{l}\text { стан ефективного використання його ресурсів і існуючих ринкових } \\
\text { можливостей, що дозволяє запобігати внутрішнім і зовнішнім загрозам і } \\
\text { забезпечувати його тривале виживання і стійкий розвиток на ринку } \\
\text { відповідно до обраної місії }\end{array}$ \\
\hline $\begin{array}{l}\text { Прокопішина О. В. } \\
{[14]}\end{array}$ & $\begin{array}{l}\text { стан оптимального для підприємства рівня використання його } \\
\text { економічного потенціалу, за якого діючі та/або можливі збитки } \\
\text { виявляються нижчими за встановлені підприємством межі }\end{array}$ \\
\hline Бєлокуров В. В. [15] & $\begin{array}{l}\text { наявність конкурентних переваг, зумовлених відповідністю } \\
\text { матеріального, фінансового, кадрового, техніко-технологічного } \\
\text { потенціалів і організаційної структури підприємства до його стратегічних } \\
\text { цілей і завдань }\end{array}$ \\
\hline Штангрет А. М. [16] & $\begin{array}{l}\text { стан захищеності життєво важливих інтересів підприємства від реальних і } \\
\text { потенційних джерел небезпеки або економічних погроз }\end{array}$ \\
\hline
\end{tabular}

Нами було встановлено перелік характеристик, що використовуються вченими в ході визначення сутності поняття «економічна безпека».

Такими характеристиками, на наш погляд, є: виживання системи; забезпечення стійкого зростання; задоволення потреб; ефективне управління; захист інтересів; зміцнення потенціалу; стабільне функціонування; збереження існуючого статусу; подолання загроз і забезпечення стійкості до них; максимізація віддачі; забезпечення конкурентоспроможності, спроможність до самовідтворення; протистояння впливу чинників. Характеристики поняття «економічна безпека» з зазначенням науковців, що робили акцент на даних характеристиках наведено в табл. 3.

За даними таблиці видно, що деякі науковці акцентували увагу на якійсь одній характеристиці економічної безпеки, вважаючи ії̈ визначальною при дослідженні сутності цього поняття. Інші виділяли декілька ключових характеристик, вважаючи, що в такий спосіб можна краще розкрити сутність цього багатогранного та складного поняття.

В роботах таких науковців, як С. Олейникова [11], Е. Микульчинова, А. Чімітова [17], , 3. Варналій [18], М. Бєндікова [19], С. Афонцева [20], Тарасевич [21] та ін. робиться акцент на тому, що економічна безпека передбачає здатність долати загрози та забезпечувати стійкість до них.

В працях С. Олейникова [11], В. Тарасевич [21] та ін. робиться акцент на тому, що економічна безпека покликана захищати інтереси (національні, суспільні, особистісні тощо). Л. Большаков, А. Архипов, А. Нестеренко [8], А. Чімітова, Е. Микульчинова [17], А. Лазарєва [22] акцентують увагу на тому, що економічна безпека покликана забезпечити стійке економічне зростання. 
Таблиця 3.

Характеристики поняття «економічна безпека»"

\begin{tabular}{|c|c|c|c|c|c|c|c|c|c|c|c|c|c|}
\hline Автор & 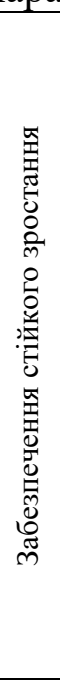 & 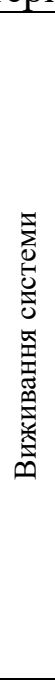 & 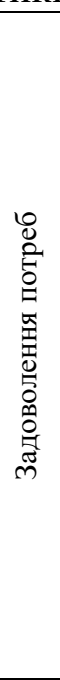 & 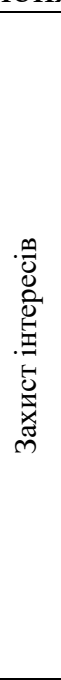 & 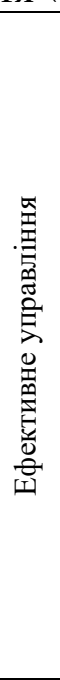 & 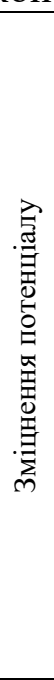 & 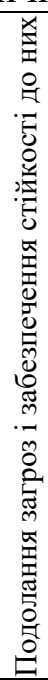 & 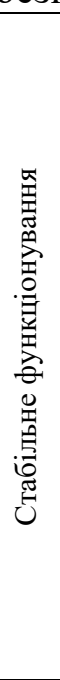 & 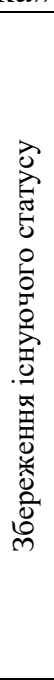 & 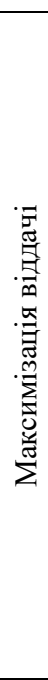 & 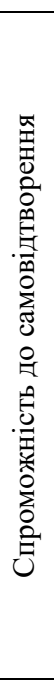 & 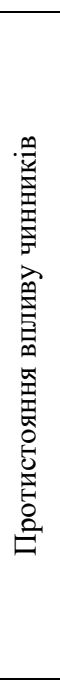 & 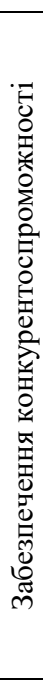 \\
\hline А. Архипов & + & & + & + & + & & & & & & & & \\
\hline С. Афонцев & & & & & & & + & & & & & & \\
\hline О. Бєлов & & & + & & & & + & & & & & & \\
\hline М. Бєндіков & & & & & & & + & & & & & & \\
\hline I. Богданов & & & & & & & & & + & & & & \\
\hline 3. Варналій & & & & & & & + & & & & & & \\
\hline О. Власюк & & + & & & & & & & & & & & \\
\hline М. Герасимов & & & & & & & & + & & & & & \\
\hline В. Духов & & & & & & & + & & & & & & \\
\hline Я. Жаліло & & & + & & & & & & & & + & + & + \\
\hline А. Іларіонов & & & & & & & & & & + & & & \\
\hline Т. Кочергіна & & & & & & & & & & & + & & \\
\hline А. Лазарєва & + & & & & & & & & & & & & \\
\hline Є. Олейников & & & & + & & + & + & + & & & & & \\
\hline М. Пендюра & & & & + & & & & & & & & & \\
\hline С. Покропивний & & & & & & & + & + & & & & & \\
\hline А. Степаненко & & & & & & & & + & & & & & \\
\hline В. Тарасевич & & & & + & & & + & & & & & & \\
\hline А. Чімітова & + & & & + & & & + & & & & & & \\
\hline
\end{tabular}

*истематизовано автором

Ефективність сучасних підприємств визначається стратегіями, спрямованими на активне використання внутрішнього потенціалу для зміни зовнішнього середовища, а не тільки до пристосування. При цьому активна адаптація $є$ процесом, що створює приріст вартості підприємства. Вважаємо, що багатогранність поняття «економічна безпека підприємства» дає змогу розглядати його з точки зору стану: ефективності використання ресурсів, виробничої системи, економічного розвитку, захищеності діяльності та інтересів, гармонізації останніх. Економічну безпеку підприємства характеризують якісні та кількісні показники, що залежать від спроможності керівництва підприємства та спеціалістів ефективно уникнути можливих загроз і ліквідувати шкідливі наслідки негативних складових зовнішнього і внутрішнього середовища підприємства.

Висновки. Проведено семантичний аналіз сутності поняття «економічна безпека», що дало змогу сформувати вичерпний перелік характеристик, які використовуються вченими в ході його визначення. На основі методу попарних порівнянь було визначено вагомість кожної характеристики та виокремлено ті характеристики, які є істотними з їх поділом на функціональні (здатність долати загрози та забезпечувати стійкість до них, здатність захищати інтереси) та результативні (здатність забезпечувати економічне 
зростання).

Базуючись на комплексному розумінні та враховуючи специфічні особливості, яких нині набула досліджувана економічна категорія, економічну безпеку підприємств визначено як систему захищеності життєво важливих і законних інтересів підприємства від зовнішніх і внутрішніх загроз в різних формах, що забезпечує його стабільний розвиток в умовах конкуренції і господарського ризику. Доведено, що завдяки функціональним характеристикам економічна безпека передбачає здатність долати загрози та забезпечувати стійкість до них, та в такий спосіб, опосередковано служить основою для досягнення очікуваного результату - забезпечення економічного зростання.

\section{Список бібліографічного опису:}

1.Вівчар О. І. Прагматизм прискорення бізнесу при моніторингу його економічної безпеки в контексті трансформаційних змін. Сталий розвиток економіки. 2014. № 1. С. 194-199.

2.Евдокимов Ф. И., Мизина Е. В. Экономическая устойчивость предприятия как фактор его безопасности. Наукові праиі Донецького національного технічного університету. Серія: економічна. 2009. № 1 (37). С. 200-216.

3.Кавун С. В. Концептуальная модель системы экономической безопасности предприятия. Науковий журнал «Економіка розвитку». 2007. № 3 (43). С. 97-101.

4.Довбня С. Б., Гічова Н. Ю. Діагностика рівня економічної безпеки підприємства. Фінанси України. 2008. № 4. С. 88-97. 5.Моделювання економічної безпеки: держава, регіон, підприємство / В. М. Геєць та ін. Харків, 2006. 240 с.

6.Дацків Р. М. Економічна безпека у глобальному вимірі. Актуальні проблеми економіки. 2004. № 7. С. 143-153.

7.Платонов А. М. Управление процессом обеспечения экономической безопасности предприятий [Електронний ресурс]. Научная электронная библиотека «Киберленинка». 2013. Режим доступу : https://cyberleninka.ru

8.Большаков А. К., Архипов А. И., Нестеренко А. Н. Экономика. Минск, 1998. 792 с.

9.Логутова Т. Г., Нагаєвський Д. І. Економічна безпека підприємства: сутність, завдання та методи забезпечення.

Теоретичні і практичні аспекти економіки та інтелектуальної власності. 2011. № 2. С. 204-207.

10. Толковый словарь ruLib.info. Режим доступу : http://www.rulib.info/default.htm

11. Олейников Е. А. Основы экономической безопасности. Москва, 1997. 233 с.

12. Ильяшенко С. И. Составляющие экономической безопасности предприятия и подходы к их оценке. Актуальні проблеми економіки. 2003. № 3 (21). С. 12-19.

13. Кузенко Т. Б. Тактичне і стратегічне планування економічної безпеки підприємства. Актуальні проблеми економіки. 2004. № 3. C. 142-151.

14. Прокопішина О. В. Управління економічною безпекою зовнішньоекономічної діяльності підприємства: автореф. дис. ... канд. ек. наук: спец. 08.00.04 - економіка та управління підприємствами / Харківський національний економічний університет. Харків, 2009. 20 с.

15. Белокуров В. В. Структура функциональных составляющих экономической безопасности предприятия [Електронний ресурс]. Вчені записки Університету «КРОК». 2005. Режим доступу: http://snku.krok.edu.ua/index.php/vcheni-zapiskiuniversitetu-krok/article/view/12

16. Штангрет А. М., Петрашова О. М. Ключові загрози забезпечення техніко-технологічної безпеки на підприємствах видавничо-поліграфічної галузі України. Економічний вісник університету. 2011. № 16 (2). С. 142-146.

17. Чимитова А. Б., Микульчинова Е. А. Вопросы устойчивого и безопасного развития региона, Улан-Удэ, 2007. 216 с.

18. Варналій 3. С., Буркальцева Д. Д., Саєнко О. С. Економічна безпека Украйни: проблеми та пріоритети зміцнення. Київ, 2011. 299 с.

19. Бендиков М. А. Экономическая безопасность промышленного предприятия в условиях кризисного развития. Менеджмент в России и за рубежом. 2000. № 2. С. 17-29.

20. Афонцев С. Национальная экономическая безопасность: на пути к теоретическому консенсусу. Мировая экономика и международные отношения. 2002. № 10. С. 30-39.

21. Тарасевич В. М. Національна економіка. Київ, 2009. 280 с.

22. Лазарева А. П. Фінансово-економічна безпека підприємства та механізм ії забезпечення. Інноваційна економіка. 2012. № 2 (6). C. 305-307.

\section{References:}

1.Vivchar O. I. (2014) Prahmatyzm pryskorennia biznesu pry monitorynhu yoho ekonomichnoi bezpeky v konteksti transformatsiinykh zmin [The pragmatism of business acceleration in monitoring its economic security in the context of transformational change]. Stalyi rozvytok ekonomiky, no. 1, pp. 194-199. (in Ukrainian)

2.Evdokimov F. I. and Mizina E. V. (2009) Ekonomicheskaya ustojchivost predpriyatiya kak faktor ego bezopasnosti [Economic sustainability of the enterprise as a factor of its security]. Naukovi praczi Doneczkogo naczionalnogo texnichnogo universitetu. Seriya: Ekonomichna, no. 1 (37), pp. 200-216. (in Russian)

3.Kavun S. V. (2007) Konceptualnaya model sistemy ekonomicheskoj bezopasnosti predpriyatiya [Conceptual model of the economic security system of an enterprise]. Naukovij zhurnal "Ekonomika rozvitku", no. 3 (43), pp. 97-101. (in Russian)

4.Dovbnia S. B. and Hichova N. Y. (2008) Diahnostyka rivnia ekonomichnoi bezpeky pidpryiemstva [Diagnosis of the level of economic security of the enterprise]. Finansy Ukrainy, по. 4, pp. 88-97. (in Ukrainian)

5.Heiets V. M., Kyzym M. O., Klebanova T. O. and Shcherniak O. I. (2006) Modeliuvannia ekonomichnoi bezpeky: derzhava, rehion, pidpryiemstvo [Modeling of economic security: state, region, enterprise]. Kharkiv: KHDUET. (in Ukrainian)

6.Datskiv R. M. (2004) Ekonomichna bezpeka u hlobalnomu vymiri [Economic security in a global dimension]. Aktualni problemy ekonomiky, по. 7, pp. 143-153. (in Ukrainian)

7.Platonov A. M. (2013) Upravlenie processom obespecheniya ekonomicheskoj bezopasnosti predpriyatij [Management of the process of ensuring the economic security of enterprises]. Available at: https://cyberleninka.ru/ (accessed 13 September 2019). (in Russian)

8.Bolshakov A. K., Arxipov A. I. and Nesterenko A. N. (1998) Ekonomika [Economics]. Minsk: Prospekt.

9.Lohutova T. H. and Nahaievskyi D. I. (2011) Ekonomichna bezpeka pidpryiemstva: sutnist, zavdannia ta metody zabezpechennia [Economic security of the enterprise: essence, tasks and methods of providing]. Teoretychni i praktychni aspekty ekonomiky ta intelektualnoi vlasnosti, pp. 204-207. (in Ukrainian)

10. Tolkoviy slovar ruLib.info [Explanatory Dictionary ruLib.info]. Available at: http://www.rulib.info/default.htm (accessed 16 
September 2019).

11. Olejnikov E. A. (1997) Osnovy ekonomicheskoj bezopasnosti [Fundamentals of Economic Security]. Moskva. (in Russian) 12. Ilyashenko S. I. (2003) Sostavlyayushhie ekonomicheskoj bezopasnosti predpriyatiya i podxody`k ix ocenke [Components of economic security of enterprises and approaches to their assessment]. Aktualni problemi ekonomiki, no. 3 (21), pp. 12-19. (in Russian)

13. Kuzenko T. B. (2004) Taktychne i stratehichne planuvannia ekonomichnoi bezpeky pidpryiemstva [Tactical and strategic planning of economic security of the enterprise]. Aktualni problemy ekonomiky, no. 3, pp. 142-151. (in Ukrainian)

14. Prokopishyna O. V. (2009) Upravlinnia ekonomichnoiu bezpekoiu zovnishnoekonomichnoi diialnosti pidpryiemstva. [Management of economic security of foreign economic activity of the enterprise]. Ph.D. in Econ. Dissertation, Kharkiv: Kharkivskyi natsionalnyi ekonomichnyi universytet. (in Ukrainian)

15. Belokurov V. V. (2005) Struktura funktsyonalnikh sostavliaiushchykh эkonomycheskoi bezopasnosty predpryiatyia [Structure of functional components of economic security of the enterprise]. Available at http://snku.krok.edu.ua/index.php/vcheni-zapiskiuniversitetu-krok/article/view/12 (accessed 13 September 2019). (in Russian)

16. Shtanhret A. M. and Petrashova O. M. (2011) Kliuchovi zahrozy zabezpechennia tekhniko-tekhnolohichnoi bezpeky na pidpryiemstvakh vydavnycho-polihrafichnoi haluzi Ukrainy [Key threats to technical and technological security at enterprises of the publishing and printing industry of Ukraine]. Ekon. visnyk universytetu, no. 16 (2), pp. 142-146. (in Ukrainian)

17. Chimitova A. B. and Mikulchinova E. A. (2007) Voprosy ustojchivogo i bezopasnogo razvitiya regiona [Issues of sustainable and safe development of the region]. Ulan-Ude: VSGTU. (in Russian)

18. Varnalii Z. S., Burkaltseva D. D. and Saienko O. S. (2011) Ekonomichna bezpeka Ukrainy: problemy ta priorytety zmitsnennia [Economy of Ukraines security: problems and priorities]. Kyiv: Znannia Ukrainy. (in Ukrainian)

19. Bendikov M. A. (2000) Ekonomicheskaya bezopasnost promyshlennogo predpriyatiya $\mathrm{v}$ usloviyax krizisnogo razvitiya [Economic security of an industrial enterprise in conditions of crisis development]. Menedzhment v Rossii i za rubezhom, no. 2, pp. 17-29. (in Russian)

20. Afoncev S. (2002) Natsyonalnaia эkonomycheskaia bezopasnost: na puty k teoretycheskomu konsensusu [National economic security: Towards a theoretical consensus]. Mirovaya ekonomika i mezhdunarodnye otnosheniya, no. 10, pp. 30-39. (in Russian) 21. Tarasevych V. M. (2009) Natsionalna ekonomika [National economy]. Kyiv: Tsentr uchbovoi literatury. (in Ukrainian) 22. Lazareva A. P. (2012) Finansovo-ekonomichna bezpeka pidpryiemstva ta mekhanizm yii zabezpechennia [Financial and economic security of the enterprise and the mechanism of its provision]. Innovatsiina ekonomika, no. 2 (6), pp. 305-307. (in Ukrainian)

Рецензент д.е.н., професор Маркіна I.A.

УДК: 631.15(477) : 005.59

Дорофєєв О.В., к.е.н., доцент

Шелковський В.Д., Летик А.І., здобувачі вищої освіти СВО «Магістр»

Полтавська державна аграрна академія

\section{КОНЦЕПТУАЛЬНІ ОСНОВИ УПРАВЛІННЯ ЕКОНОМІЧНИМ РОЗВИТКОМ СІЛЬСЬКОГОСПОДАРСЬКИХ ПІДПРИЕМСТВ НА ПРИНЦИПАХ ГАРМОНІЙНОСТІ}

У статті розглянуто історичні аспекти виникнення криз аграрного виробництва. Зроблено припущення, що аграрна криза є свідченням порушення економічних пропорцій в системі аграрного виробництва. Взаємозв'язок і співвідношення певних показників економічної діяльності підприємств має відбуватися із дотриманням пропорцій у процесі зміни стану системи. Мова йде не про встановлення оптимальних значень показників, а про управління економічним розвитком сільськогосподарських підприємств та забезпечення їх ефективного функціонування у довгостроковому періоді на принципах гармонійності.

Ключові слова: управління розвитком, економічний розвиток, принципи гармонійності, сільськогосподарські підприємства.

Dorofyeyev O., Shelkovskyi V., Letyk A.

\section{CONCEPTUAL BASIS OF MANAGEMENT OF ECONOMIC DEVELOPMENT OF AGRICULTURAL ENTERPRISES ON THE PRINCIPLES OF HARMONY}

The historical aspects of occurrence of crises in agricultural production are considered in the article. The assumption that the agrarian crisis is evidence of a violation of economic proportions in the agricultural production system was made. The interconnection and correlation of certain indicators of enterprises economic activity should be kept in accordance with the proportions in the process of changing the system state. It is not about setting the optimum indicators value, but about managing the economic development of agricultural enterprises and ensuring their effective functioning in the long term on the principles of harmony.

Keywords: development management, economic development, principles of harmony, agricultural 